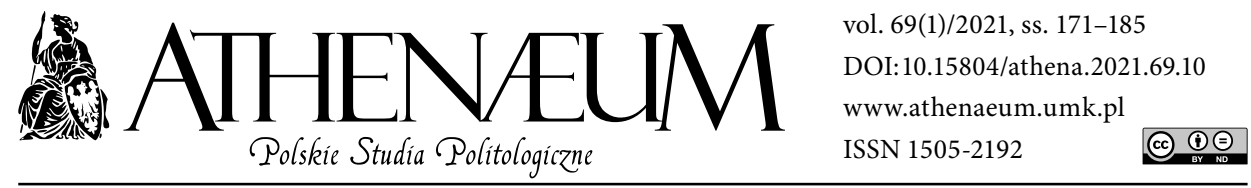

\title{
DWUKADENCYJNOŚĆ WÓJTÓW, BURMISTRZÓW I PREZYDENTÓW MIAST W POLSCE W OPINIACH ELEKTORATÓW UGRUPOWAŃ I KOMITETÓW WYBORCZYCH W WYBORACH DO SEJMIKÓW WOJEWÓDZTW W 2018 ROKU
}

\author{
BICAMERALISM OF VILLAGE HEADS, MAYORS AND CITY \\ PRESIDENTS IN POLAND IN THE OPINIONS OF ELECTORATES \\ OF ELECTORAL GROUPS AND ELECTION COMMITTEES IN \\ THE 2018 ELECTIONS TO PROVINCIAL ASSEMBLIES
}

\section{Dominik Szczepański*๑}

\begin{abstract}
ABSTRAKT
Celem artykułu było przedstawienie zagadnienia związanego $\mathrm{z}$ ograniczeniem liczby kadencji włodarzy w Polsce. Analizie poddano dane empiryczne, pochodzące z badań ankietowych, w których zapytano respondentów o to, czy opowiadali się za ograniczeniem możliwości sprawowania funkcji wójta, burmistrza oraz prezydenta miasta do dwóch kadencji. Zmiennymi, które wzięto pod uwagę, były: udział ankietowanych w wyborach samorządowych w 2018 roku, deklarowany udział $\mathrm{w}$ wyborach parlamentarnych, deklarowane poglądy, deklarowana religijność oraz wiek respondentów.
\end{abstract}


Badania ankietowe zostały przeprowadzone w okresie od grudnia 2018 r. do lutego 2019 r. w ramach ogólnopolskiego projektu badawczego pt. „Preferencje polityczne. Postawy - identyfikacje - zachowania" realizowanego od $2009 \mathrm{r}$.

Słowa kluczowe: Polska; system wyborczy; wybory lokalne; system polityczny; ograniczenie kadencji research project entitled "Political Preferences: Attitudes - Identifications - Behaviors", carried out since 2009 .

Keywords: Poland; local government; elections; political system; term limit

\section{WPROWADZENIE}

Ustawowe regulacje dotyczące ograniczenia liczby kadencji włodarzy wybieranych w trakcie demokratycznych wyborów obowiązują tylko w niektórych państwach europejskich. Jak podkreślił Piotr Wawrzyk, funkcjonują one w różnych wymiarach, np. w postaci działających przepisów lub też jako rozwiązanie będące wynikiem przeprowadzonej debaty publicznej. Ich celem było (i jest nadal) przeciwdziałanie sytuacjom, w którym te same osoby przez długi czas pełnią funkcje w organach uchwałodawczych lub wykonawczych samorządu, co może prowadzić do wytworzenia lokalnych układów, korupcji, nepotyzmu i klientelizmu (Wawrzyk, 2017, s. 108).

Do najbardziej znanych przykładów stosowania rozwiązań polegających na ograniczeniu liczby kadencji w samorządach lokalnych w Europie możemy zaliczyć Niemcy, Włochy i Portugalię, natomiast w znacznie szerszym układzie odniesienia Stany Zjednoczone ${ }^{1}$.

W Niemczech, gdzie mamy do czynienia $\mathrm{z}$ federalną strukturą kraju, przepisy dotyczące samorządu terytorialnego są wydawane odrębnie przez każde z 16 krajów związkowych. Długość kadencji władz wynosi w poszczególnych landach od czterech do dwunastu lat, przy czym należy pamiętać, iż w wielu krajach obowiązuje ograniczenie wiekowe kandydatów, którzy w chwili objęcia urzędu burmistrzów nie mogą mieć ukończonych 65 lat. We Włoszech kadencja burmistrza wynosi 5 lat. Istnieje tam ograniczenie możliwości ubiegania się o trzecią kadencję, z wyjątkiem burmistrzów reprezentujących małe miejscowości,

1 Oprócz wyżej podanych przykładów warto również zwrócić uwagę na Szwajcarię, gdzie w zaledwie kilku gminach limity kadencji są wprowadzane w drodze prawa lokalnego, a nie odgórnie (Gendźwiłł, Swianiewicz, 2017). 
w których liczba mieszkańców nie przekracza 3 tysięcy. W Portugalii występuje ograniczenie do trzech kadencji burmistrza, sprawowanych przez 4 lata, jednak zgodnie z ustawą z 29 września 2013 r. zwaną potocznie Prawem Ograniczonego Mandatu ograniczono liczbę kadencji burmistrzów i prezydentów miast. Przewidywała ona „całkowity zakaz pełnienia tych funkcji w przypadku osób, które trzy razy z rzędu piastowały to stanowisko. Ustawa została jednak zaskarżona do Trybunału Konstytucyjnego, który w swoim orzeczeniu uznał, że osoba pełniąca funkcję przez trzy następujące po sobie kadencje może ubiegać się ponownie o to stanowisko, ale już na terenie innej jednostki samorządowej. Następnie może wrócić do swojej gminy na kolejne trzy kadencje" (Wawrzyk, 2017, s. 108).

W przypadku Stanów Zjednoczonych kadencja urzędników wybieranych wraz z prezydentem USA wynosi 2 lata $^{2}$. Nieco inaczej sytuacja ta wygląda w odniesieniu do poszczególnych stanów. W mieście Nowy Jork liczba sprawowanych kadencji odnosząca się do niemal wszystkich urzędów politycznych jest ograniczona wyłącznie do 2 lub 3 kadencji; w Cincinnati ograniczenie takie występuje do dwóch następujących po sobie kadencji, natomiast w Filadelfii burmistrz może zostać wybrany nie więcej niż na trzy następujące po sobie kadencje (Roszkowski, 2017, s. 90).

Oprócz wskazanej wyżej praktyki stosowania ograniczenia liczby kadencji w samorządach lokalnych warto podkreślić, iż kwestia ta stanowi również istotny element debaty publicznej prowadzonej m.in. w Norwegii, Francji, Bułgarii, Albanii i Chorwacji. Prowadzone tam rozmowy mają póki co charakter wstępny, gdyż wszelkie rozwiązania, które były poddawane pod dyskusję, dotyczyły możliwości wprowadzenia ograniczenia liczby kadencji do 2 lub 3. We wszystkich wymienionych przypadkach, a więc zarówno w państwach, gdzie obowiązuje ustawowa regulacja ograniczająca limit kadencji, jak i w państwach, w których prowadzona jest debata publiczna nad wprowadzeniem takiego rozwiązania, wykorzystuje się argument nie tylko wymiany lokalnych elit politycznych, ale przede wszystkim pobudzenia świadomości i aktywności obywateli poprzez ich częstsze uczestnictwo w elekcjach wyborczych, i tym samym zwiększenie odpowiedzialności za sprawy loklane.

2 Interesujących ustaleń na temat tradycji samorządu terytorialnego w Ameryce oraz trybu wyboru organów samorządu terytorialnego w USA dokonała Agnieszka Pawłowska (2016, ss. 17-75 i 147-167). 


\section{DWUKADENCYJNOŚĆ W POLSCE}

Idea ograniczająca możliwość sprawowania funkcji wójta, burmistrza i prezydenta miasta w Polsce nie jest rozwiązaniem nowym, bowiem, jak podkreślili Adam Gendźwiłł i Paweł Swianiewicz, jeszcze pod koniec lat dziewięćdziesiątych XX wieku obawiano się zjawiska zbyt dużej rotacji na stanowiskach włodarzy, co miało przeszkadzać „w konsekwentnej realizacji spójnych wizji rozwoju jednostek lokalnych" (Gendźwiłł, Swianiewicz, 2017). Częściową realizacją tego zamierzenia było wprowadzenie ustawy z 20 czerwca 2002 r. o bezpośrednim wyborze wójta, burmistrza i prezydenta miasta przez ogół mieszkańców (Dz.U. $2002 \mathrm{nr} 113$ poz. 984).

To właśnie podczas prac nad wspomnianą ustawą doszło do zgłoszenia przez Sojusz Lewicy Demokratycznej (SLD) poselskiego projektu ustawy o bezpośrednim wyborze wójta gminy, w którym określono zasady oraz tryb wyboru wójta w gminie liczącej do 20 tys. mieszkańców. W projekcie tym wskazano, iż wójt wybierany był na czteroletnią kadencję i mógł zostać ponownie wybrany w tej samie gminie tylko raz (art. 2 ust.2). Celem wnioskodawców było wówczas „usprawnienie funkcjonowania organów samorządu terytorialnego", a także „ułatwienie profesjonalizacji kadr administracji samorządowej” (Druk nr 154, IV kadencja Sejmu RP). W wyniku dalszego procesu legislacyjnego sugerowana propozycja została odrzucona i nie trafiła ostatecznie do projektu ustawy skierowanego do II czytania (Tarasek, 2016, s. 85).

Po raz kolejny propozycja limitowania kadencji władz samorządowych pojawiła się w zapowiedzi polityków Prawa i Sprawiedliwości (PiS) po wygranych wyborach parlamentarnych w 2005 r. W lutym 2006 r. politycy tej formacji politycznej zaproponowali zmianę polegającą na ograniczeniu biernego prawa wyborczego, zgodnie z którą osoba pełniąca funkcję wójta, burmistrza lub prezydenta miasta mogłaby sprawować swój urząd tylko przez dwie kadencje (Kacprzak). Propozycję tę oceniono w kuluarach partii jako podstawę umożliwiającą zlikwidowanie powiązań rodzinno-przyjacielskich, towarzyszących obsadzaniu stanowisk w jednostkach samorządu terytorialnego. Z kolei Przewodniczący Klubu Parlamentarnego PiS, Przemysław Gosiewski, stwierdził wówczas, iż ograniczenie kadencji wójtów burmistrzów i prezydentów miast służyć miało głównie wymianie elit oraz władz lokalnych i zarazem przysłużyć się wzmocnieniu demokracji (Kacprzak). Ze względu na liczną krytykę pomysłu ograniczającego kadencyjność organów wykonaw- 
czych jednostek samorządu terytorialnego projektu ustawy w tym zakresie nie przygotowano ${ }^{3}$.

Częściowym powrotem do wspomnianej koncepcji ograniczającej bierne prawo wyborcze był projekt ustawy o zmianie ustawy o samorządzie gminnym oraz o zmianie innych ustaw zgłoszony przez polityków PiS w dniu 21 września 2010 r. W projekcie tym, a dokładnie $\mathrm{w}$ art. 3 ust. 4, zaproponowano poprawkę w brzmieniu: „kandydatem na wójta nie może być osoba, która pełniła już tę funkcję przez co najmniej 2 kadencje" (Druk nr 3834, VI kadencja Sejmu RP). W uzasadnieniu podano niemal identyczne przykłady zastosowania ograniczeń kadencyjności włodarzy, jak te pochodzące z 2006 r., a następnie jako przykład praktycznego wskazania istniejącego już takiego limitu przytoczono przykład ustawy o wyborze Prezydenta Rzeczypospolitej Polskiej z 27 września 1990 r., w której w art. $8^{\mathrm{a}}$ ust. 1 wskazano, iż urząd ten można pełnić tylko przez dwie kadencje. Co ważne, argumentując projektowaną zmianę ustawy, stwierdzono: „Piastowanie funkcji wójta, burmistrza i prezydenta miasta przez więcej nić dwie kadencje stwarza zagrożenie zawłaszczenia tego urzędu przez określoną grupę lokalną, rodzinną, czy środowisko polityczne, stworzenia zagrożenia powstania trudnych do przezwyciężenia powiązań i korupcji”" (Druk nr 3834, VI kadencja Sejmu RP). Pomimo uznania zgłoszonego projektu przez Komisję Ustawodawczą Sejmu oraz Biuro Analiz Sejmowych za dopuszczalny i zgodny z Konstytucją RP, Sejm VI kadencji nie skierował go do I czytania i tym samym 1 kwietnia 2011 r. projekt odrzucono.

Do identycznej koncepcji limitowania kadencji wójtów PiS powróciło na początku VII kadencji Sejmu, kiedy to grupa posłów złożyła w dniu 22 listopada 2011 r. poselski projekt ustawy o zmianie ustawy o samorządzie gminnym oraz o zmianie innych ustaw (Druk nr 428, VII kadencja Sejmu RP). Projekt ten został skierowany do I czytania w dniu 23 maja 2012 r., a następnie 15 czerwca 2012 r. został odrzucony w trakcie głosowania.

Warto podkreślić, iż w trakcie VII kadencji Sejmu propozycję limitowania kadencji wójtów, burmistrzów oraz prezydentów miast przedłożyli w dniu 9 listopada 2012 r. posłowie reprezentujący Klub Parlamentarny Ruchu Palikota. Zakładał on nowelizację ustawy z 5 stycznia 2011 r. - Kodeks wyborczy, gdzie postulowana zmiana dotyczyła art. 472 a, w którym zaproponowano, iż: „Kan-

3 O stanowisku przedstawicieli środowisk samorządowych wobec propozycji zgłoszonej przez PiS w 2006 r. szerzej patrz: (Marszałek-Kawa, 2018, ss. 753 i nast.). 
dydatem na wójta nie może być osoba, która pełniła już tę funkcję w tej samej gminie przez co najmniej 2 kadencje" (Druk nr 1015, VII kadencja Sejmu RP). Projekt ten stał się przedmiotem I czytania w dniu 8 lutego 2013 r. i w trakcie głosowania został on odrzucony, przy czym nie zniechęciło to przedstawicieli klubu ponieważ - jak słusznie zauważył Krzysztof Skotnicki - jesienią 2013 r. posłowie Ruchu Palikota zaproponowali, „aby ograniczenie możliwości kandydowania z uwagi na odbyte już dwie kadencje dotyczyło nie tylko wójtów (burmistrzów, prezydentów miast), ale również posłów i senatorów" (Skotnicki, 2018, s. 9). Do uchwalenia projektowanych zmian ostatecznie nie doszło.

Najbardziej radykalną zmianę w zakresie postulowanych zmian przyniosły zapowiedzi Jarosława Kaczyńskiego ze stycznia 2017 r. dotyczące wprowadzenia zmiany zasad wybierania wójtów, burmistrzów i prezydentów miast. Argument ten podtrzymywali w publicznych wypowiedziach także czołowi politycy PiS, w tym również ówczesna Prezes Rady Ministrów, Beata Szydło (Wrzalik, 2018, s. 129). Dyskusje te nabrały szczególnej intensyfikacji w roku poprzedzającym wybory samorządowe zaplanowane na 2018 r., tym bardziej że sugerowane zmiany limitowania kadencji władz samorządowych miały zacząć obowiązywać od nowej kadencji samorządu. Obawy te były o tyle uzasadnione, iż zdecydowana większość parlamentarna, którą posiadał PiS od 2015 r. w ramach obozu Zjednoczonej Prawicy, stwarzała realne możliwości wprowadzenia nowych regulacji (Kowalik, 2016, ss. 51-66; Adamowicz, 2014, ss. 24-52; Czerw, 2017, ss. 81-92).

Rządowy projekt ustawy o zmianie niektórych ustaw w celu zwiększenia udziału obywateli w procesie wybierania, funkcjonowania i kontrolowania niektórych organów publicznych został zgłoszony w Sejmie w dniu 10 listopada 2017 r., natomiast trzy dni później skierowano go do I czytania oraz przesłano do opinii organizacji samorządowych (Druk nr 2001, VIII kadencja Sejmu RP). Ostatecznie regulacja dotycząca ograniczenia liczby kadencji włodarzy wybieranych w wyborach demokratycznych została wprowadzona ustawą z dnia 11 stycznia 2018 r. o zmianie niektórych ustaw w celu zwiększenia udziału obywateli w procesie wybierania, funkcjonowania i kontrolowania niektórych organów publicznych (Dz. U. z 2018 r. poz. 130, 1349) (Patyra, 2017, ss. 23-34; Składkowski, 2019, ss. 5-15; Skotnicki, 2018, ss. 11-16; Izdebski, 2017).

Na potrzeby poniższych analiz postawiono następujące pytania badawcze: 1) jaki był stosunek respondentów wobec wprowadzenia limitowania kadencji wójtów, burmistrzów oraz prezydentów miast? 2) czy deklarowane poglądy ankietowanych stanowiły odzwierciedlenie rzeczywistych podziałów poli- 
tycznych w Sejmie VIII kadencji (rządzący versus opozycja)? 3) w jaki sposób najmłodsi respondenci opowiedzieli się za wprowadzonymi regulacjami?

\section{METODOLOGIA BADAŃ}

Badania ankietowe zostały przeprowadzone okresie od grudnia 2018 r. do lutego 2019 r. na reprezentatywnej, ogólnopolskiej próbie dorosłych Polaków, dobranej w sposób kwotowo-warstwowy (N=970). Próbę dobrano w sposób warstwowo-kwotowy ( $\mathrm{N}=970)$. Populacja została podzielona na warstwy, które stanowiły województwa $(\mathrm{N}=16)$. W badanej grupie znalazło się łącznie 509 kobiet $(52,4 \%)$ oraz 462 mężczyzn (47,6\%). Przy doborze kwotowym uwzględniono takie zmienne, jak płeć, wiek i miejsce zamieszkania (w układzie wieś - miasto). Szczegóły te zestawiono w Tabeli 1.

Realizacja badań możliwa była dzięki udziałowi Autora w ogólnopolskim projekcie badawczym pt. „Preferencje polityczne. Postawy - identyfikacje zachowania" kontynuowanym od 2009 r. Przy tworzeniu kwestionariusza ankiety wykorzystano najpopularniejszą w naukach społecznych pięciostopniową skalę Likerta, umożliwiającą uzyskanie odpowiedzi nie tylko o stopniu badanego zjawiska, ale przede wszystkim dotyczącej akceptacji poglądów respondentów.

Jeśli chodzi o dobór poszczególnych osób do badania, zdecydowano się na dobór losowy. Ankiety przeprowadzono w ramach wywiadów bezpośrednich. Uczestniczyli w nich pracownicy naukowi reprezentujący 12 ośrodków akademickich w Polsce (Uniwersytet Warszawski, Uniwersytet Warmińsko-Mazurski, Uniwersytet Gdański, Uniwersytet Mikołaja Kopernika w Toruniu, Uniwersytet Zielonogórski, Uniwersytet Adama Mickiewicza w Poznaniu, Uniwersytet Szczeciński, Katolicki Uniwersytet Lubelski, Uniwersytet Jana Kochanowskiego w Kielcach, Uniwersytet Śląski, Uniwersytet Rzeszowski i Uniwersytet Wrocławski). Głównym koordynatorem badań był prof. zw. dr hab. Robert Alberski (Uniwersytet Wrocławski). Przeprowadzenie powyższych badań możliwe było dzięki realizacji tzw. zadań własnych, realizowanych przez wymienione wyżej ośrodki akademickie, finansowanych z subwencji Ministerstwa Nauki i Szkolnictwa Wyższego.

Tabela 1. Próba kwotowo-warstwowa badań wraz ze zmiennymi 


\begin{tabular}{|c|c|c|c|c|c|c|}
\hline \multirow{2}{*}{ 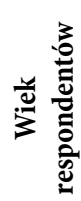 } & 18-24 lata & 25-34 lata & 35-44 lata & 45-54 lata & $\begin{array}{c}55-64 \\
\text { lata }\end{array}$ & $\begin{array}{c}\text { powyżej } \\
65 \text { lat }\end{array}$ \\
\hline & $\begin{array}{c}N=105 \\
10,8 \%\end{array}$ & $\begin{array}{c}N=181 \\
18,6 \%\end{array}$ & $\begin{array}{c}\mathrm{N}=183 \\
18,8 \%\end{array}$ & $\begin{array}{c}N=151 \\
15,6 \%\end{array}$ & $\begin{array}{c}N=156 \\
16,1 \%\end{array}$ & $\begin{array}{l}N=194 \\
20,0 \%\end{array}$ \\
\hline \multirow{2}{*}{ 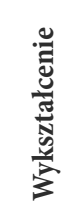 } & $\begin{array}{c}\text { wykształ- } \\
\text { cenie/bez } \\
\text { wykształcenia }\end{array}$ & $\begin{array}{l}\text { podstawowe/ } \\
\text { gimnazjalne }\end{array}$ & zawodowe & $\begin{array}{l}\text { średnie/ } \\
\text { policealne }\end{array}$ & \multicolumn{2}{|c|}{$\begin{array}{c}\text { wyższe - ukończone } \\
\text { studia licencjackie lub } \\
\text { magisterskie }\end{array}$} \\
\hline & $\begin{array}{l}N=7 \\
0,7 \%\end{array}$ & $\begin{array}{c}\mathrm{N}=42 \\
4,3 \%\end{array}$ & $\begin{array}{c}N=132 \\
13,6 \%\end{array}$ & $\begin{array}{l}N=384 \\
39,5 \%\end{array}$ & \multicolumn{2}{|c|}{$\begin{array}{l}N=399 \\
41,1 \%\end{array}$} \\
\hline \multirow{2}{*}{ 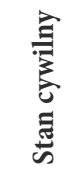 } & $\begin{array}{l}\text { panna/ } \\
\text { kawaler }\end{array}$ & $\begin{array}{l}\text { zamężna/ } \\
\text { żonaty }\end{array}$ & $\begin{array}{l}\text { rozwódka/ } \\
\text { rozwodnik }\end{array}$ & \multicolumn{2}{|c|}{$\begin{array}{l}\text { wdowa/ } \\
\text { wdowiec }\end{array}$} & \multirow{3}{*}{$\begin{array}{l}\text { miasto powy- } \\
\text { żej } 200 \text { tys. } \\
\text { mieszkańców }\end{array}$} \\
\hline & $\begin{array}{l}N=219 \\
22,6 \%\end{array}$ & $\begin{array}{c}\mathrm{N}=571 \\
58,8 \%\end{array}$ & $\begin{array}{c}\mathrm{N}=72 \\
7,4 \%\end{array}$ & $\begin{array}{l}\mathrm{N}= \\
8,7\end{array}$ & & \\
\hline \multirow{2}{*}{ 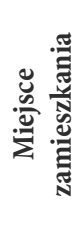 } & wieś & $\begin{array}{c}\text { miasto } \\
\text { do } 20 \text { tys. } \\
\text { mieszkańców }\end{array}$ & $\begin{array}{c}\text { miasto } \\
20-100 \text { tys. } \\
\text { mieszkańców }\end{array}$ & \multicolumn{2}{|c|}{$\begin{array}{l}\text { miasto 100-200 tys. } \\
\text { mieszkańców }\end{array}$} & \\
\hline & $\begin{array}{c}\mathrm{N}=366 \\
37,7 \%\end{array}$ & $\begin{array}{c}\mathrm{N}=104 \\
10,7 \%\end{array}$ & $\begin{array}{c}\mathrm{N}=172 \\
17,7 \%\end{array}$ & \multicolumn{2}{|c|}{$\begin{array}{c}\mathrm{N}=124 \\
12,8 \%\end{array}$} & $\begin{array}{l}N=204 \\
21,0 \%\end{array}$ \\
\hline
\end{tabular}

Źródło: opracowanie własne.

Badania zrealizowano przy użyciu kwestionariusza ankiety anonimowej, dzięki czemu respondenci chętniej odpowiadali na stawiane pytania. Przeprowadzono je we wszystkich województwach w Polsce po zakończonych wyborach do sejmików województw w 2018 r. Autor poniższych rozważań odpowiedzialny był za koordynację badań w województwie podkarpackim.

Zebrane odpowiedzi podzielono w oparciu o cztery kategorie, a mianowicie: 1) poparcie dla partii i komitetów wyborczych w wyborach samorządowych (do sejmików województw) 2) poparcie dla partii politycznych w wyborach parlamentarnych (planowanych na 2019 r.) 3) deklarowane poglądy oraz 4) wiek. 


\section{ELEKTORATY UGRUPOWAŃ I KOMITETÓW WYBORCZYCH WOBEC DWUKADENCYJNOŚCI WÓJTÓW BURMISTRZÓW I PREZYDENTÓW MIAST}

Z przeprowadzonych badań wynika, iż elektoraty poszczególnych partii politycznych, w tym również koalicji i komitetów wyborczych, wyraźnie zarysowały podział na zwolenników i przeciwników limitowania kadencyjności wójtów, burmistrzów oraz prezydentów miast. Oś podziału stanowili respondenci popierający Zjednoczoną Prawicę, gdzie aż 31,42\% ankietowanych opowiedziało się za ograniczeniem możliwości sprawowania funkcji wójta, burmistrza i prezydenta miasta (odpowiedź zdecydowanie tak), natomiast 26,55\% pytanych udzieliło odpowiedzi raczej tak oraz wyborcy komitetu Kukiz'15, którzy wykazali się większą determinacją w poparciu omawianych ograniczeń $(38,24 \%$ dla odpowiedzi zdecydowanie tak i 29,41\% dla odpowiedzi raczej tak). Zdecydowanymi oponentami takich regulacji ustawowych byli wyborcy nie tylko Koalicji Obywatelskiej (30,74\% głosujących dla odpowiedzi raczej nie i 20,78\% w wariancie zdecydowanie nie), ale również SLD Lewica Razem (31,71\% dla odpowiedzi raczej nie i $20,78 \%$ dla odpowiedzi zdecydowanie nie) i PSL (26,15\% dla odpowiedzi raczej nie i $20 \%$ w wariancie zdecydowanie nie). Dane te szczegółowo zestawiono na Wykresie 1.

Sporym zaskoczeniem okazały się wyniki badań przeprowadzone w grupie wyborców popierających lokalne komitety wyborcze oraz w kategorii „Inne” i „Nie pamiętam”. We wszystkich tych przypadkach największy odsetek ankietowanych był przeciwny wprowadzeniu limitowania kadencji władz wójtów, burmistrzów oraz prezydentów miast, przy czym na względnie podobnym poziomie respondenci wskazali odpowiedzi „trudno powiedzieć” oraz „raczej tak" (Wykres 1).

Udzielone w ten sposób odpowiedzi mogły jasno wskazywać nie tylko na samo poparcie wprowadzonego ograniczenia, ale także wynikającą z tego możliwość wymiany lokalnych elit politycznych, zwiększenie udziału obywateli $\mathrm{w}$ procesie partycypowania w akcie głosowania i tym samym wzięcia większej odpowiedzialności za sprawy lokalne związane z rozwojem danego województwa.

Powyższy trend uwzględniający wspomnianą już oś podziału został również utrzymany w przypadku respondentów zapytanych o to, na kogo oddaliby głos w nadchodzących wyborach parlamentarnych w 2019 r. Dotyczyło to również ankietowanych wymienionych w kategorii „Nie głosowałabym/nie głosowałbym” oraz „Inne” (Wykres 2). 
[180]
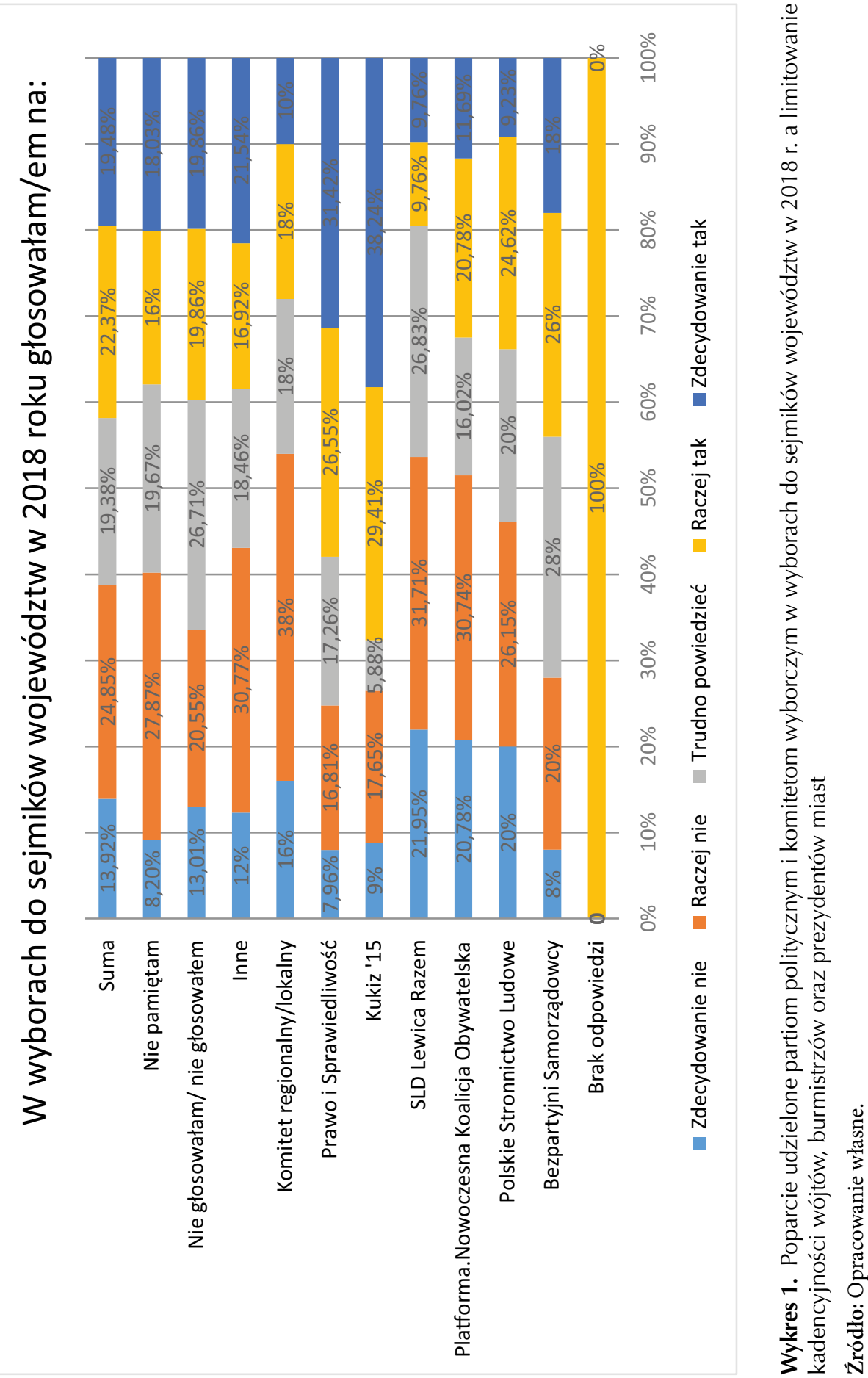
[181]

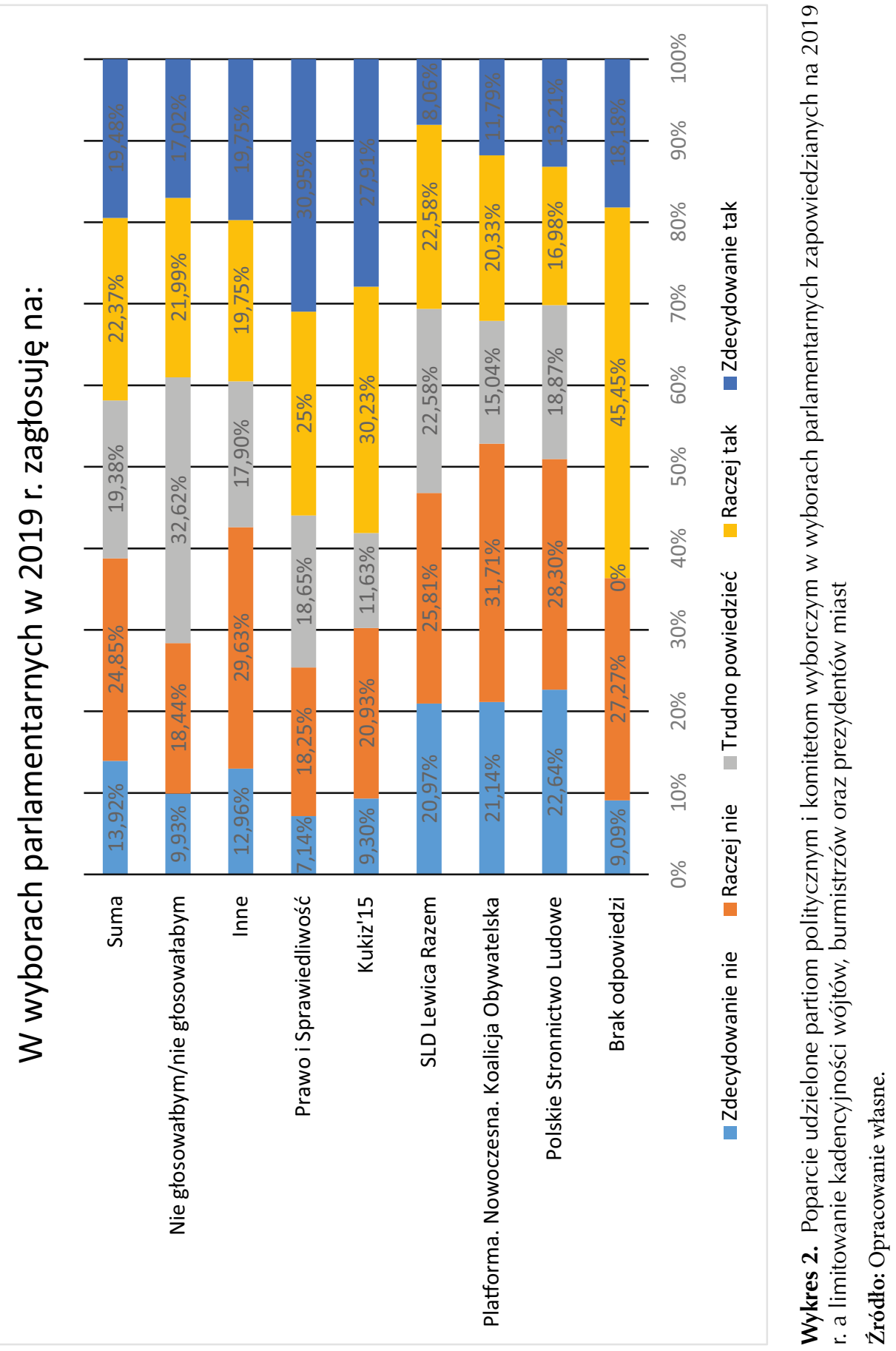


Szczególnie widocznym aspektem związanym z uwypukleniem podziału respondentów opowiadających się za wprowadzeniem ograniczenia kadencyjności wójtów, burmistrzów oraz prezydentów miast a ich zdecydowanymi przeciwnikami były deklarowane poglądy ankietowanych. W badanej grupie największy odsetek stanowili wyborcy określający swoje poglądy jako prawicowe, spośród których aż 28,09\% opowiedziało się zdecydowanie za wprowadzeniem limitowania kadencji, natomiast $22,84 \%$ popierało tę regulację. Zaskoczeniem okazały się jednak odpowiedzi udzielone przez wskazaną grupę ankietowanych, gdzie aż 23,46 było przeciwnych takiej regulacji.

Na względnie podobnym poziomie (oczywiście w poszczególnych kategoriach odpowiedzi) oscylowały wyniki respondentów o poglądach lewicowych i centrum dotyczące negowania wprowadzenia ograniczeń kadencyjności włodarzy (Wykres 3). W tej grupie respondentów interesujące okazały się także wyniki tej części wyborców, którzy nie potrafili sprecyzować deklarowanych poglądów, gdzie aż 27,6\% respondentów nie określiło się względem tego, czy popierali wprowadzoną regulację limitowania kadencji włodarzy czy też nie, natomiast $24,4 \%$ ankietowanych $w$ tej grupie opowiedziało się przeciw, a $21,2 \%$ popierało takie rozwiązanie.

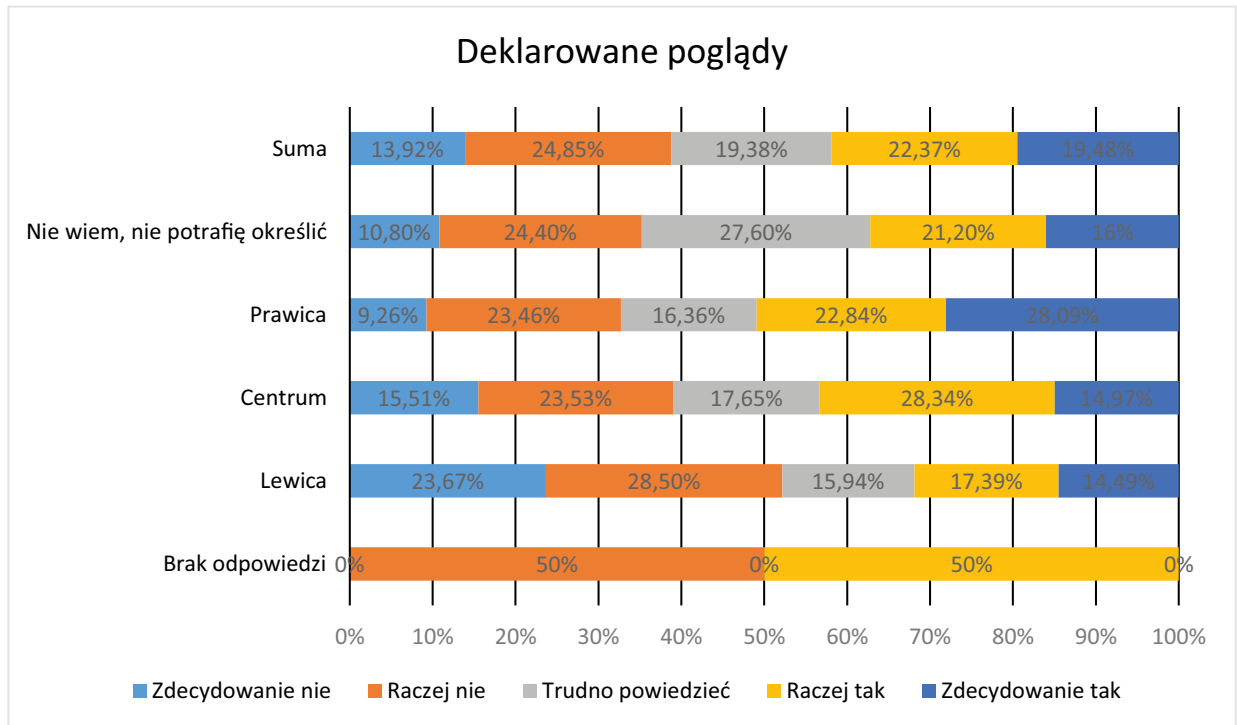

Wykres 3. Deklarowane poglądy respondentów a limitowanie kadencyjności wójtów, burmistrzów oraz prezydentów miast

Źródło: Opracowanie własne. 
Z ostatniej zmiennej, jaką był wiek respondentów, wynika, iż największą grupę przeciwników wprowadzania limitowani kadencji wójtów, burmistrzów oraz prezydentów miast stanowiły osoby w wieku: $25-34$ lata $(28,73 \%), 45-54$ lata $(26,49 \%)$ oraz ankietowani w przedziale wiekowym $18-24$ lata $(25,71 \%)$. W grupie wiekowej 55-64 lata przeważała akceptacja dla wprowadzonych regulacji związanych z limitowaniem kadencji włodarzy (27,56\% głosów), przy czym warto podkreślić, iż na odpowiedź 'trudno powiedzieć' w tej grupie wskazało o 3,2\% ankietowanych mniej.

W pozostałych grupach wiekowych udzielone odpowiedzi były na względnie podobnym poziomie, co dotyczyło odpowiedzi zarówno popierających, jak i negujących ograniczenie kadencji władz samorządowych (Wykres 4).

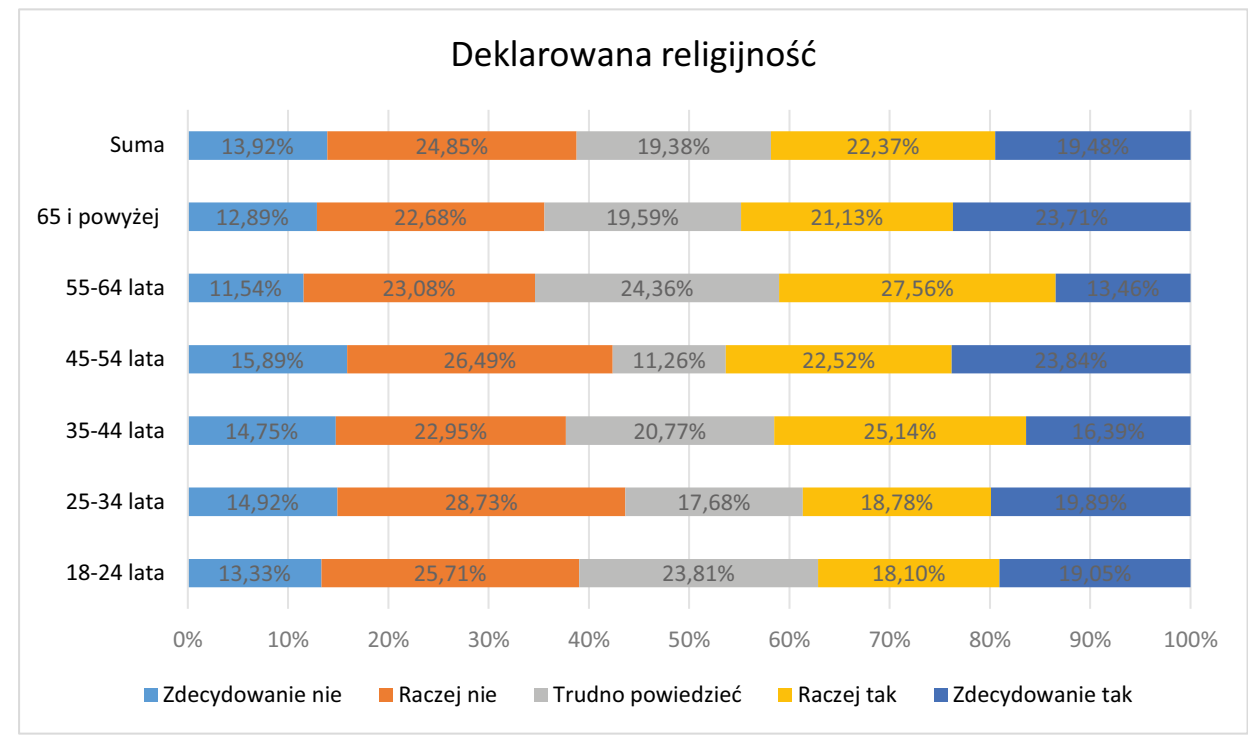

Wykres 4. Deklarowany wiek respondentów a limitowanie kadencyjności wójtów, burmistrzów oraz prezydentów miast

Źródło: Opracowanie własne.

\section{PODSUMOWANIE}

Niezależnie od dyskusji, jaka toczyła się pomiędzy zwolennikami oraz przeciwnikami wprowadzenia ustawowych regulacji, należy uznać, iż ostateczna decyzja o tym, kto powinien kandydować na urząd wójta, burmistrza czy prezydenta miasta, powinnna pozostać wyłącznie w gestii społeczności lokalnych oraz 
samych zainteresowanych, bez jakiejkolwiek ingerencji polityków na szczeblu centralnym.

Udzielając odpowiedzi na dwa pierwsze pytania postawione na początku artykułu, należy stwierdzić, iż respondenci w sporej mierze popierali wprowadzenie limitowania kadencji wójtów, burmistrzów oraz prezydentów miast. Główną oś podziału stanowili zwolennicy wprowadzonych regulacji, sytuujący się po prawej stronie sceny politycznej i popierający głównie Zjednoczoną Prawicę oraz komitet Kukiz'15. Zdecydowanymi oponentami tych ograniczeń byli przedstawiciele opowiadający się za szeroko rozumianą opozycją tworzoną głównie przez PO, SLD i PSL. Dotyczyło to również komitetów określonych w ramach zmiennej o nazwie inne i tzw. lokalne komitety wyborcze.

Odpowiadając na trzecie pytanie, należy zauważyć, iż największymi przeciwnikami wprowadzania limitowani kadencji wójtów, burmistrzów oraz prezydentów miast były zdecydowanie młode osoby w wieku od 18-24 lat, a także w pozostałym przedziale wieku, tj. od 25 do 54 lat. Takie podejście może świadczyć nie tylko o właściwym rozumieniu istoty demokracji lokalnej, ale również o wyraźnym sprzeciwie wobec ograniczania mieszkańców wspólnoty samorządowej dotyczącej swobodnego decydowania o losach swoich małych ojczyzn.

Powyższe badania nie wypełniają wszystkich znamion uczestnictwa elektoratów partii politycznych i komitetów wyborczych w sferze aktywności obywatelskiej. W związku z tym należy stwierdzić, iż badania te powinny zostać znacznie poszerzone poprzez wprowadzenie szeregu nowych zmiennych, takich jak: płeć respondentów, miejsce zamieszkania (miasto/wieś) czy wykształcenie. Dzięki sugerowanym propozycjom możliwe byłoby precyzyjne określenie konkretnych grup wyborców oraz znacznie lepsze przybliżenie omawianego zagadnienia.

\section{BiBLIOGRAFIA:}

Adamowicz, A. (2014). ,Jak będę wiedział, że to moja ostatnia kadencja, to robię, co chcę" czyli wielogłos o ograniczaniu kadencyjności wójta, burmistrza i prezydenta miasta. Kwartalnik Naukowy OAP UW e-Politikon, 11.

Czerw, J. (2017). Zasady wyboru wójta - stan aktualny i zgłaszane propozycje zmian. W: M. Chrzanowski, J. Sobczak (red.). Samorzady w procesie decentralizacji władzy publicznej. Lublin: Stowarzyszenie Naukowe Pro Scientia Juridica.

Druk nr 154, IV kadencja Sejmu RP.F

Druk nr 3834, VI kadencja Sejmu RP.

Druk nr 428, VII kadencja Sejmu RP.

Druk nr 1015, VII kadencja Sejmu RP 
Druk nr 2001, VIII kadencja Sejmu RP.

Gendźwiłł, A., Swianiewicz, P. (2017). Czy potrzebujemy limitu kadencji w samorzadzie? Warszawa. Pobrane z: http://www.batory.org.pl/upload/files/Programy\%20 operacyjne/Masz\%20Glos/Czy-potrzebujemy-limitu-kadencji-w-samorzadzie.pdf. Izdebski, H. (2017). Konstytucyjna dopuszczalność ograniczenia liczby kadencji wójtów, burmistrzów, prezydentów miast ze skutkiem od najbliższych wyborów w odniesieniu do osób obecnie piastujących mandat. Warszawa. Pobrane z: https://www.batory. org.pl/publikacja/konstytucyjna-dopuszczalnosc-ograniczenia-liczby-kadencjiwojtow-burmistrzow-prezydentow-miast-ze-skutkiem-od-najblizszych-wyboroww-odniesieniu-do-osob-obecnie-piastujacych-mandat/.

Kacprzak, I. (2021). Nowy pomysł Prawa i Sprawiedliwości na wybory samorzadowe. Pobrane z: https://wisla.naszemiasto.pl/nowy-pomysl-prawa-i-sprawiedliwoscina-wybory-samorzadowe/ar/c1-6335951.

Kowalik, J. (2016). Kondycja społeczeństwa obywatelskiego w kontekście idei limitowania kadencji wójtów, burmistrzów, prezydentów miast. Acta Politica Polonica, 3.

Marszałek-Kawa, J. (2018). Reflections on the Proposal to Introduce a Term Limit for Elected Officials Effects and Implications. Polish Political Science Yearbook, 47.

Patyra, S. (2017). Zakres dopuszczalnej ingerencji władzy centralnej w sferę funkcjonowania samorządu terytorialnego w Polsce - refleksje aksjologiczne. W: M. Chrzanowski, J. Sobczak (red.). Samorządy w procesie decentralizacji władzy publicznej. Lublin: Stowarzyszenie Naukowe Pro Scientia Juridica.

Pawłowska, A. (2016). Samorząd terytorialny w Stanach Zjednoczonych Ameryki. Warszawa.

Roszkowski, J. (2017). Koncepcja ograniczenia liczby kadencji wójta (burmistrza, prezydenta miasta) w ujęciu prawnoustrojowym. W: I. Wieczorek, M. Mazuryk (red.). Wybrane aspekty ograniczenia liczby kadencji organów wykonawczych gminy. Łódź: Wydawnictwo Narodowego Instytutu Samorządu Terytorialnego.

Składkowski, K. (2019). Ograniczenie w liczbie kadencji w wyborach prezydentów, burmistrzów i wójtów, Finanse komunalne, 3.

Skotnicki, K. (2018). W sprawie dopuszczalności zakazu reelekcji wójta (burmistrza, prezydenta miasta) po piastowaniu urzędu przez dwie kadencje. Wrocławskie Studia Politologiczne, 24.

Tarasek, M. (2016). Wprowadzenie ograniczenia kadencyjności wójta, burmistrza i prezydenta miasta w pracach polskiego parlamentu. Polityka i Społeczeństwo, 2.

Ustawa z 20 czerwca 2002 r. o bezpośrednim wyborze wójta, burmistrza i prezydenta miasta przez ogół mieszkańców (Dz.U. 2002 nr 113 poz. 984).

Wawrzyk, P. (2017). Ograniczenie liczby kadencji w samorządach lokalnych w Europie. W:I. Wieczorek, M. Mazuryk (red.). Wybrane aspekty ograniczenia liczby kadencji organów wykonawczych gminy. Łódź: Wydawnictwo Narodowego Instytutu Samorządu Terytorialnego.

Wrzalik, M. (2018). Ograniczenie możliwości kandydowania na wójta (burmistrza, prezydenta miasta) po piastowaniu urzędu przez dwie kadencje. Athenaeum. Polskie Studia Politologiczne, 58, 128-138. DOI: 10.15804/athena.2018.58.08. 